\title{
当院の透析患者の四肢・体幹の特発性出血に関する検討
}

\author{
崔啓子栗田宜明西隆 博三瀬直 \\ 多川斉杉本 徳一郎 \\ 三井記念病院腎臟内科
}

キーワード: 特発性出血, 透析患者

〈要旨〉

【背景】維持透析患者での特発性の出血の特徵を明らかにすることを目的とした.【方法と結果】対象は 1987 年 1 月から 2007 年 8 月の間に, 当院に特発性出血のため入院した, もしくは入院中に特発性に医学管理を要する出血を 発症した維持透析患者 11 例 (男性 9 例, 女性 2 例) である. 出血は特発性に限り, また消化管, 脳, 眼底, バスキュ ラーアクセス関連の出血および播種性血管内凝固症候群に伴う出血は除外した. 10 例が血液透析患者, 1 例が腹膜 透析患者であった. 出血のイベントは計 13 件認め, 腎周囲出血 5 件, 後腹膜出血 2 件, 腹腔内出血 1 件, 腹直筋内 出血 1 件, 大網出血 1 件, 下肢動脈出血 3 件であった. 平均年齢は $59 \pm 12$ (36 81) 歳, 平均透析歴は $14 \pm 10$ (5 32) 年, 原疾患は慢性糸球体腎炎 9 例, 腎硬化症 2 例であった. 関連因子として抗血小板薬使用 (2 例), 抗凝固薬 使用 (4 例), 高血圧患者（8 例）があつた. 無痛性出血は 4 件認めた. 治療は経皮的動脈塞栓術 7 件, 外科的手術 1 件, 保存的治療 5 件であった. 10 例は軽快退院し, 1 例は入院中に他疾患で死亡した.【考察】透析患者の特発性 出血には腎不全による血小板機能障害のほか, 透析歴, 薬剤, 血圧など多因子が関与する. 典型的には疼痛症状を 伴うが，時に疼痛を呈さない例もあるので，急速な貧血や血圧低下の際の鑑別診断に重要と思われる.

\section{Clinical characteristics of spontaneous hemorrhage in dialysis patients}

Keiko Sai, Noriaki Kurita, Takahiro Nishi, Naobumi Mise, Hitoshi Tagawa and Tokuichiro Sugimoto Department of Nephrology, Mitsui Memorial Hospital

Key words : spontaneous hemorrhage, dialysis patient

\section{〈Abstract〉}

Background: Dialysis patients have bleeding tendency and we sometimes encounter cases with a significant amount of spontaneous hemorrhage. Method and result: Between January 1987 and August 2007, 11 dialysis patients ( 9 men and 2 women) were diagnosed as having spontaneous bleeding on admission or during hospitalization. There were 13 events in these 11 patients ; 5 in the perirenal space, 3 in the lower extremities, 2 in the retroperitonium, 1 each in the abdominal cavity, omentum, and rectus abdominis. We did not include gastrointestinal, cerebrovascular, ophthalmic or vascular access-related hemorrhages. Ten patients were on hemodialysis, and 1 patient was on peritoneal dialysis. The average age and dialysis period were 59 \pm 12 (36 81) and $14 \pm 10 \quad(5 \sim 32)$ years, respectively. Nine patients demonstrated chronic glomerulonephritis, whereas 2 were diagnosed as nephrosclerosis. Two patients used anti-platelet drugs, and 4 patients were under anticoagulant treatment. Eight patients had hypertension. Transcatheter arterial embolization was needed in 7 events, and surgical repair was performed in 1 event. The remaining 5 events were followed conservatively. Among these 11 patients 10 patients were discharged after recovery, but one patient died of myocardial infarction during hospitalization. Discussion: Spontaneous bleeding can be affected by factors such as platelet dysfunction, drug use and blood pressure. Spontaneous hemorrhage should be considered when acute anemia or hypotension is noted in dialysis patients.

\footnotetext{
崔 啓子 三井記念病院腎藏内科％ 101-8643 東京都千代田区神田和泉町 1
}

Keiko Sai Tel : 03-3862-9111 Fax : 03-3862-7765

〔受付日：2008 年 4 月 14 日, 受理日：2008 年 10 月 30 日〕 


\section{I . 背 景}

日本の透析患者の死因の $1.9 \%$ が出血であり ${ }^{1)}$, 出 血は透析患者の重大な合併症のひとつである．尿毒症 患者の出血傾向の主因は貧血に加えて血小板機能不全 と考えられ, 出血時間は延長している ラーアクセスの穿刺部からの出血の持続, 鼻出血, 消 化管出血, 泌尿器系出血, 硬膜下血腫の頻度が高い. 治療は透析による尿毒症の改善, 輸血や遺伝子組み換 えヒトエリスロポエチン製剤（rHuEPO）による貧血 の改善, デスモプレシン, エストロゲンが有効とされ ている ${ }^{4 \sim 6)}$.

透析患者では頭蓋内，消化管，アクセス関連以外の 出血（特発性出血）も多く発症する. 当院での特発性 出血について, 過去 20 年間の症例をまとめその臨床 的特徵を明らかにすることを試みた。

\section{II. 方 法}

1987 年 1 月から 2007 年 8 月の 20 年間に, 特発性出 血のため当院に入院した，もしくは入院中に特発性出 血を発症した維持透析患者 11 例における 13 件の出血 イベントについて検討した，特発性出血は外傷によら ない体内出血とし, 後天性腎囊胞 (ACDK) から出血 した症例，抗血小板薬，抗凝固薬などの影響が考えら
れる症例なども含んだ。ただし，頭蓋内出血，消化管 出血, 大動脈出血, バスキュラーアクセス関連の出血 は除外した。

\section{III. 結 果}

11 症例による 13 件の特発性出血を表 1 , 表 2 に示 す. 男性 9 例，女性 2 例であり，症例 (5)では 3 件の出 血イベントがあった．年齢は $59 \pm 12 （ 36 〜 81 ）$ 歳で あった．血液透析（HD）10 例, 腹膜透析（PD）1例で あった。平均透析歴は $14 \pm 10(5 \sim 32)$ 年であった。 原疾患は慢性系球体腎炎 (chronic glomerulonephritis,

\begin{tabular}{|c|c|}
\hline 症例 & $\begin{array}{l}11 \text { 例 (13 件) } \\
\text { 男性 } 9 \text { 例, 女性 } 2 \text { 例 }\end{array}$ \\
\hline 年齢（歳） & $59 \pm 12 （ 36 \sim 81 ）$ 歳※ \\
\hline 透析方法 & 血液透析 10 例, 腹膜透析 1 例 \\
\hline 透析歴（年） & $14 \pm 10 （ 5 \sim 32 ）$ 年※ \\
\hline 原疾患 & $\begin{array}{l}\text { 慢性糸球体腎炎 } 9 \text { 例 } \\
\text { 腎硬化症 } 2 \text { 例 }\end{array}$ \\
\hline 出血部位 & $\begin{array}{l}\text { 胃周囲出血 } 5 \text { 件 } \\
\text { 後腹膜出血（腎以外） } 2 \text { 件 } \\
\text { 腹腔内出血 } 2 \text { 件 } \\
\text { 大網出血 } 1 \text { 件 } \\
\text { 腹直筋内出血 } 1 \text { 件 } \\
\text { 下肢動脈出血 } 3 \text { 件 }\end{array}$ \\
\hline
\end{tabular}

※平均値士標準偏差を示す.

表 2 特発性出血を発症した 13 症例のまとめ

\begin{tabular}{|c|c|c|c|c|c|c|c|c|c|c|c|c|}
\hline & $\begin{array}{l}\text { 年齢 } \\
\text { (歳) }\end{array}$ & 性別 & 部位 & 原疾患 & $\begin{array}{l}\text { 透析 } \\
\text { 年数 }\end{array}$ & 高血压 & 薬 & $\begin{array}{c}\text { 診断時 } \\
\mathrm{Hb}(\mathrm{g} / \mathrm{dL})\end{array}$ & 症状 & 治療 & 予後 & 備考 \\
\hline (1) & 59 & 男 & 腎 & CGN & 23 & あり & - & 7.6 & 血尿 & TAE & 軽快 & \\
\hline (2) & 46 & 男 & 腎 & NSC & 10 & あり & 凝 & 7.6 & 背部痛 & TAE & 軽快 & PT-INR 1.67 \\
\hline (3) & 56 & 男 & 腎 & CGN & 9 & あり & 血 & 8.5 & 背部痛 & TAE & 軽快 & \\
\hline (4) & 56 & 男 & 腎 & CGN & 10 & あり & - & 9.7 & 背部痛 & TAE & 軽快 & \\
\hline \multirow[t]{3}{*}{ (5) } & 36 & 女 & 腎 & CGN & 10 & あり & - & 5.3 & 背部痛 & TAE & 軽快 & \\
\hline & 42 & & 右大腿 & CGN & 17 & あり & - & 5.1 & 疼痛 & 保存的 & 軽快 & \\
\hline & 43 & & 左大腿 & CGN & 18 & あり & - & 4.4 & 疼痛 & 保存的 & 軽快 & \\
\hline (6) & 72 & 男 & 後腹膜胸腔 & NSC & 9 & あり & 凝 & 6.9 & 貧血 & TAE & 軽快＃ & APTT 49.4 \\
\hline (7) & 50 & 男 & 後腹膜 & CGN & 12 & あり & - & 6.3 & 腹痛, 発熱 & 手術＃＃ & 軽快 & \\
\hline 8 & 81 & 女 & 腹腔 (大網) & CGN & 5 & なし & 凝 & 7.2 & 貧血 & 保存的 & 軽快 & PT-INR 6.3 \\
\hline (9) & 62 & 男 & 腹腔 (大網) & CGN & 5 & あり & - & 6.1 & ショック & TAE & 軽快 & \\
\hline (10) & 58 & 男 & 腹直筋 & CGN & 32 & なし & - & 10.4 & 腹痛 & 保存的 & 軽快 & \\
\hline (11) & 69 & 男 & 下腿 & CGN & 31 & なし & 血, 凝 & 9.9 & 疼痛 & 保存的 & 軽快 & PT-INR 2.8 \\
\hline
\end{tabular}

CGN : chronic glomerulonephritis, NSC : nephrosclerosis, TAE : transcatheter arterial embolism 凝：抗凝固薬, 血：抗血小板薬 \#後腹膜, 胸腔出血は TAE にて軽快したものの，入院中に AMI のため死亡した.

\# \#腹痛で受診し, CT から虫垂周囲膿瘍を疑い開腹したものの腹腔内血腫でありドレナージのみ行った. 
CGN） 9 例，腎硬化症（nephrosclerosis, NSC） 2 例で あった。出血部位は腎周囲出血 5 件，腎以外の後腹膜 出血 2 件, 腹腔内出血 1 件, 腹直筋内出血 1 件, 大網 出血 1 件, 下肢動脈出血 3 件であった.

$<$ 症例 (1) (4) >

腎周囲出血の症例である。全例が後天性腎囊胞 （ACDK）を合併していた. 比較的若年患者が多く， 全例が経皮的動脈塞栓術 (transcatheter arterial embolization, TAE) で軽快した。症例 (2) はワーファリ ン内服中であったが, PT-INR 1.67 とコントロール 良好であった。症例 (4)のコンピューター断層撮影 (computed tomography, CT) 画像を図 1 に示す.

$<$ 症例 (5) $>$

唯一の PD 症例で, 26 歳 PD 導入, 36 歳腎周囲出血, 42 歳および 43 歳時に下腿出血を発症した。腎周囲出

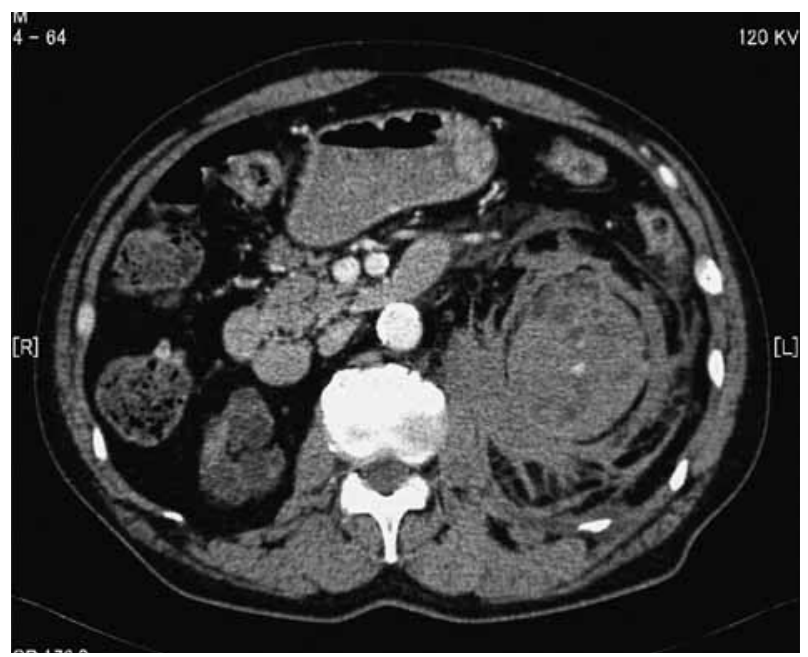

図 1 症例 (4)

疼痛で発症した左腎周囲出血の症例である. 腎被膜下に造影剤の extravasation を認める。
血はTAEを要したが, 下腿出血は保存的に軽快した。 $<$ 症例 (6) $>$

63 歳, NSC で HD 導入した. 72 歳で中枢神経障害 と脳浮腫のため集中治療室 (ICU) 内で持続式血液透 析滤過 (CHDF) を行っていた際に, 複数の部位から の出血をきたした（図 2). 抗凝固薬として 1 日あたり 約 7,200 単位の低分子へパリンを使用中であったが, APTT 49.4 とコントロールは良好であった．貧血の 進行 $(\mathrm{Hb} 9 \rightarrow 6 \mathrm{~g} / \mathrm{dL})$ と広範な皮下血腫で気づいた。 後腹膜出血および胸腔内出血を同時期に数回繰り返 し，TAEにより良好に止血が得られた，後に急性心 筋梗塞により死亡した。

$<$ 症例 (7) $>$

38 歳, CGN から HD 導入, 50 歳, 腹痛, 発熱のため 受診し，CTにて虫垂周囲に膿瘍を疑う所見を認め, 外科的に試験開腹したが, 局所には感染徵候は認めず 血腫を認めるのみであり, ドレナージにて軽快した。 $<$ 症例 8>

76 歳, CGN から HD 導入. 81 歳, 進行する貧血を 呈し精查の腹部エコーで巨大な大網血腫を認めた（図 3). 心房細動のためワーファリン内服中（PT-INR= 6.3) であり，これが誘因となった可能性がある.

$<$ 症例 (10) >

透析歴 32 年の長期透析例である. 26 歳で CGN の ため HD 導入. 58 歳, 腹痛のため受診し CT, MRI で 腹直筋血腫と診断した。 TAE が技術的に困難である こと, および, 診断以降増大傾向を認めなかったこと から経過観察し軽快した（図 4).

$<$ 症例 (11) $>$

透析歴 31 年と長期透析例である. 38 歳, CGN から HD 導入. 69 歳時, バスキュラーアクセストラブルで

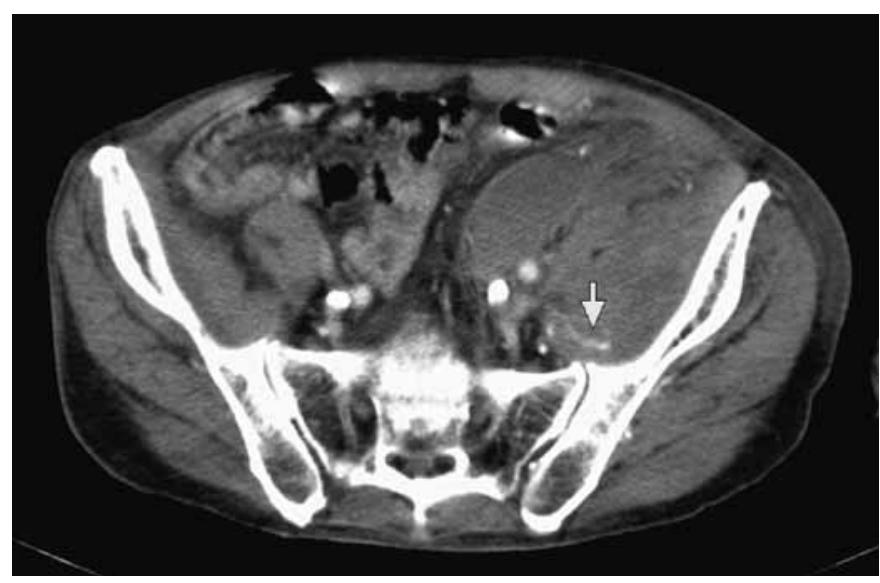

図 2 症例 (6)

ICU にて CHDF を行っていた症例である. 低分子へパリンを使用中であった. 後腹膜, 胸腔内出血を繰り返した. 


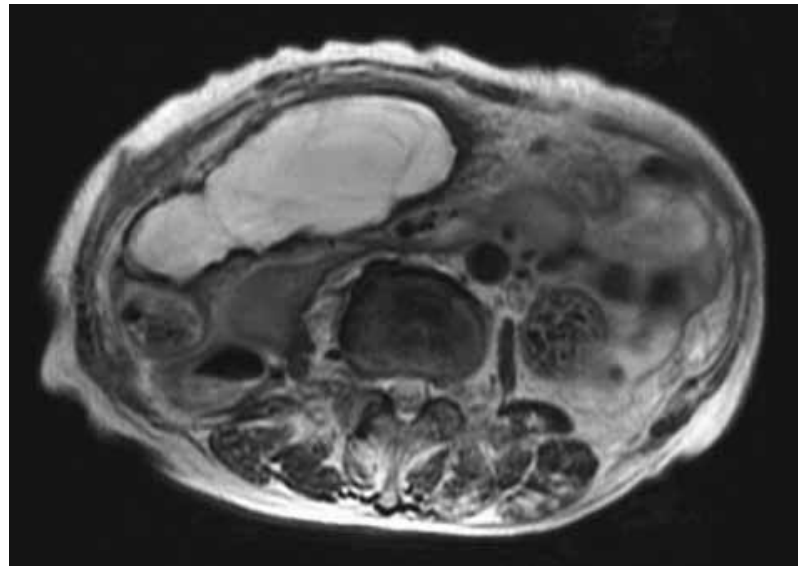

図 3 症例 (8)

進行する貧血のため精査目的で超音波を行ったと ころ，偶然大網周囲の血腫を認めた。

入院中に腓骨動脈からの出血で急速な下腿腫脹を認め た. 大動脈弁置換術後（機械弁）でワーファリン内服 中，また冠動脈形成術 (PCI) 後で抗血小板薬 2 剂内服 中であった．ワーファリンコントロールは問題を認め なかった。

症例 (8) 以外では全例で最大 12 単位の輸血を行っ た

原疾患は慢性系球体腎炎が多く，高血圧合併患者が 多かった。症状は疼痛が最も多く, 治療は多くで TAEが有効である. 出血のみに起因する死亡は認め なかった.

\section{IV. 考 察}

透析患者の出血傾向について, 高窒素血症と出血時 間の延長とは直接関係がないといわれている 毒素物質の蓄積により血小板機能不全をきたすと考え られており，クレアチンやメチルグアニジンなどの関 与が想定され，血小板自体の異常および血小板と血管 内皮細胞の相互関係異常が血小板機能不全をきたすと 考えられている．血小板自体の表面糖タンパクのひと つである GP II b/III a 異常により，粘着能および凝集 能が障害される の接着を介する血小板の凝集および，また血管内皮細 胞の von Willebrand 因子 ( vWF) との結合による血 小板の粘着に関わる。.このほか, 血小板 $\alpha$ 顆粒からの アデノシン 2 リン酸 (ADP) やセロトニンの放出異常, アラキドン酸, プロスタンディン代謝異常, 血小板卜 ロンボキサン $\mathrm{A}_{2}$ 産生低下なども血小板機能異常の原 因として知られている ${ }^{10)}$. 血小板以外の問題では, 貧 血の関与, 一酸化窒素（NO）産生増加, vWF 異常な

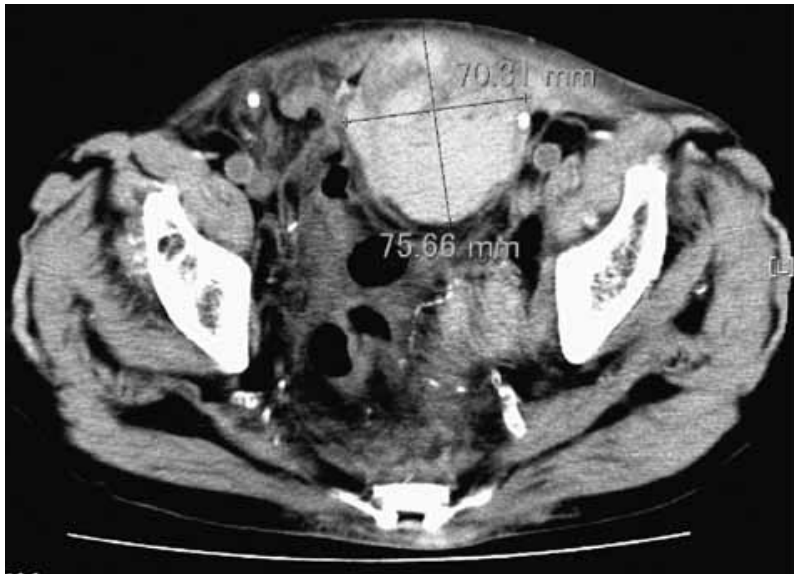

図 4 症例 (10)

腹痛のため受診し MRIにて腹直筋内血腫と診断。 保存的に軽快した。

どが報告されている。一方，腎不全患者では，通常は プロトロンビン時間 (PT), 部分トロンボプラスチン 時間（APTT）などの凝固系パラメーターは正常であ る. 血小板数は正常もしくは若干の低下が多い. 出血 傾向に対する治療は透析による尿毒症の改善, 輸血や rHuEPO による貧血の改善, デスモプレシン, エスト ロゲンなどが有効であることが示されている ${ }^{11}$.

本報告は，当院での約 20 年間での特発性出血の透 析患者症例をまとめたものである。透析患者の特発性 出血についての報告は, 門口ら ${ }^{12)}$ の腎周囲血腫 10 例 についての報告がある. また後腹膜出血, 四肢の出血. などは一例報告〜数例での症例報告がなされている.

当院での観察では, 11 例のうち 9 例が透析歴 9 年以 上であり，透析長期例が多かった。高血圧合併例が 8 例, 抗血小板薬の使用例は 2 例，抗凝固薬の使用例は 4 例であり，特に抗凝固薬の使用が多かった。出血部 位は腎周囲が 5 件と最多で, 平均透析歴は 12 年で, 全 例が ACDK を合併していた．血液透析を 4 年以上行 われている患者では $74 \%$ ACDK を認め ${ }^{13)}$, ACDK の出血合併症は多く報告されている ${ }^{14,15)}$. ACDKの出 血の主症状は疼痛であるが，貧血や血圧低下などで偶 然発見される疼痛のない症例が 4 件あり, 注意を要す ると思われた。また来院時に $\mathrm{Hb} 9.0 \mathrm{~g} / \mathrm{dL}$ 以上と著 明な貧血を認めない症例が 3 例存在し, 貧血のない症 例でも特発性出血を除外できないことに注意を要する と思われた．保存的に軽快したのは 5 件であり，8件 でTAEなどの侵襲的治療を要した。腎周囲出血では 全例 TAE を要したが, 下肢の皮下出血では全例が保 存的に軽快した。門口ら ${ }^{12)}$ の腎周囲出血 10 症例の報 告では, $\mathrm{HD}$ 患者 9 名, PD 患者 1 名で HD 患者におい て透析年数は短く，年齢は高いという特徴があるとし 
ている。

われわれの 11 例のうち，糖尿病性腎症の患者はい なかった．これは出血例では長期透析例が多く，糖尿 病患者では 10 年以上の透析例が少ないためかも知れ ない. 長期透析患者で中膜の石灰化が全身で進行する ことが特発性出血にかかわる小血管の脆弱性と関連し ているのかもしれない.

今回の特発性出血は比較的長期透析例に多く, 主症 状は疼痛であったＴAEが治療として有効であった が, 保存的に軽快する例も半数で認めた. 特発性出血 での死亡はなかった。 ほかに, 文献例では, 腸腰筋出 血, 脾出血の特発性出血の報告例がある ${ }^{16,17)}$.

本報告では透析患者の広義の特発性出血の症例を検 討した，外傷によらない特発性出血には，腎不全以外 の誘因を認めない狭義の特発性出血に加え, 抗血小板 薬, 抗凝固薬, ACDK の存在などが影響していると考 えられる広義の特発性出血を認めた。

\section{結語}

透析患者の特発性出血は長期透析例に多く，多くは 侵襲的治療を要する，疼痛を伴わない症例も存在し， 急速な貧血や血圧低下の際の鑑別診断に重要と思われ る.

\section{文献}

1）「わが国の慢性透析療法の現況 2006 年 12 月 31 日現 在」. 日本透析医学会, 統計調査委員会

2) Rath CE, Mailliard JA, Schreiner GE : Bleeding tendency in uremia. N Engl J Med 257 : 808-811, 1957

3) Escolar G, Diaz-Ricart M, Cases A : Uremic platelet dysfunction : past and present. Curr Hematol Rep 4 : 359-367, 2005

4) Weigert AL, Schafer AI : Uremic bleeding : pathogenesis and therapy. Am J Med Sci 316 : 94-104, 1998

5) Mannucci PM, Remuzzi G, Pusineri F, Lombardi R,
Valsecchi C, Mecca G, Zimmerman TS : Deamino-8$\mathrm{D}$-arginine vasopressin shortens the bleeding time in uremia. N Engl J Med 308 : 8-12, 1983

6) Mannucci PM : Hemostatic drugs. N Engl J Med 339 : 245-253, 1998

7) Steiner RW, Coggins C, Carvalho AC : Bleeding time in uremia : A useful test to assess clinical bleeding. Am J Hematol $7:$ 107-117, 1979

8) Weigert AL, Schafer AI : Uremic bleeding : pathogenesis and therapy. Am J Med Sci 316 : 94-104, 1998

9) Escola G, Cases A, Bastida E, Garrido M, Lopez J, Revert L, Castillo R, Ordinas A : Uremic platelets have a functional defect affecting the interaction of von Willebrand factor with glycoprotein II b- III a. Blood $76: 1336-1340,1990$

10）前島 司，高橋 進，波多野道信：慢性腎不全におけ る血小板凝集能一全血血小板凝集能とグアニジノ化合 物. 日腎会誌 $33: 201-212,1991$

11) Hedges SJ, Dehoney SB, Hooper JS, Amanzadeh J, Busti AJ : Evidence-based treatment recommendations for uremic bleeding. Nat Clin Pract Nephrol 3 : 138-153, 2007

12）門口 啓, 乳原善文, 田上哲夫, 比嘉康志, 野村和史, 星野純一, 澤 直樹, 香取秀幸, 竹本文美, 高市憲明： 当院維持透析患者における腎出血 10 例の検討. 透析 会誌 39 (Suppl 1)：997，2006

13) Ishikawa I, Aquired cystic disease : Mechanism and manifestations. Semin Nephrol 11 : 671-684, 1991

14) Moore AE, Kujubu DA : Spontaneous retroperitoneal hemorrhage due to acquired cystic kidney disease. Hemodial Int 11: S38-40, 2007

15) Levine $\mathrm{E}:$ Aquired cystic kidney disease. Radiol Clin North Am 34 : 947-964, 1996

16) Bhasin HK, Dana CL : Spontaneous retroperitoneal hemorrhage in chronically hemodialyzed patients. Nephron $22: 322-327,1978$

17) Milutinovich J, Follette WC, Scribner BH : Spontaneous retroperitoneal bleeding in patients on chronic hemodialysis. Ann Intern Med 86 : 189-192, 1977 